\title{
Fetal origins of insulin resistance and obesity
}

\author{
Claire J. Stocker*, Jonathan R. S. Arch and Michael A. Cawthorne \\ Clore Laboratory, University of Buckingham, Hunter Street, Buckingham MK18 1EG, UK
}

\begin{abstract}
A number of epidemiological studies worldwide have demonstrated a relationship between poor early growth and an increased susceptibility to insulin resistance, visceral obesity, type 2 diabetes and other features of the metabolic syndrome in adulthood. However, the mechanistic basis of this relationship and the relative roles of genes and the environment remain a subject of debate. The 'thrifty phenotype' hypothesis proposes that poor fetal nutrition leads to programming of metabolism and an adult phenotype that is adapted to poor but not plentiful nutrition. The maternal reduced-protein rat model has been used to examine the importance of the maternal environment in determining susceptibility to adult disease. Pregnant and lactating rat dams are fed a diet containing $80 \mathrm{~g}$ protein $/ \mathrm{kg}$ as compared with $200 \mathrm{~g}$ protein $/ \mathrm{kg}$, which leads to growth restriction in utero. Offspring of low-protein dams have increased susceptibility to diabetes, insulin resistance and hypertension when fed a palatable high-fat diet that promotes obesity. Administration of leptin during pregnancy and lactation to these protein-restricted dams produces offspring that have increased metabolic rate and do not become obese or insulin resistant when fed on a high-fat diet. Increased glucocorticoid exposure, particularly during late gestation, has been linked with insulin resistance in adulthood. High levels of fetal glucocorticoids may result from a decreased activity of placental $11 \beta$-hydroxysteroid dehydrogenase (11ß-HSD) type 2 , which normally protects the fetus from high maternal glucocorticoid levels. Leptin administration to protein-restricted dams inhibits the suppression of $11 \beta-H S D-2$ and may be one mechanism by which the metabolic syndrome is prevented.
\end{abstract}

Intrauterine growth restriction: Low birth weight: Obesity: Insulin resistance

\section{Evidence for the early origins of adult disease}

Low birth weight remains an important public health problem in many countries. It may be a consequence of premature birth, genetic programming or intrauterine growth restriction. Intrauterine growth restriction is predominantly affected by the maternal diet, placental function, infection and underlying social factors. The focus of the present article is on low birth weight resulting from intrauterine growth restriction and the relationship between being small-forgestational age and the susceptibility for adult disease.

The relationship between early growth and the later occurrence of insulin resistance, type 2 diabetes, hypertension, hyperlipidaemia and CVD has been documented in studies of both men and women in distinct populations in the UK, mainland Europe, Asia, Africa and the USA (Newsome et al. 2003). In one early study it was found that men who are the smallest at birth $(<2.5 \mathrm{~kg})$ are almost seven times more likely to be glucose intolerant or type 2 diabetic than those who are the heaviest at birth $(>4.3 \mathrm{~kg}$; Hales et al. 1991). An even stronger relationship has been observed between birth weight and the presence of the metabolic syndrome (glucose intolerance, hypertension and elevated triacylglycerol content), with those men who are smallest at birth being eighteen times more likely to have the syndrome at the time of study than those who are the heaviest at birth (Barker et al. 1993). The combination of low birth weight followed by obesity in later life appears to carry the highest risk of insulin resistance. The persisting high incidence of intrauterine growth restriction and a worldwide increase in obesity probably contributes to the rise in CVD and type 2 diabetes in developing countries (Fall, 2001). However, the molecular basis of this association is largely unknown, and the relative roles played by both genetic and environmental factors are still a subject of intense debate.

\footnotetext{
Abbreviation: $11 \beta$-HSD, 11ß-hydroxysteroid dehydrogenase.
*Corresponding author: Dr C. J. Stocker, fax +44 1280 820135, email claire.stocker@buckingham.ac.uk
} 


\section{Genes $v$. the environment}

There is evidence that paternal factors or genes influence fetal growth and later susceptibility to diabetes. The 'fetal insulin' hypothesis suggests that low birth weight and type 2 diabetes are two independent consequences of the same insulin-resistant genotype (Frayling \& Hattersley, 2001). One cause of insulin resistance might be from mutations in the gene encoding glucokinase, which have been shown to be associated with reduced birth weight and the appearance of maturity-onset type 2 diabetes of the young (Hattersley et al. 1998; Njolstad et al. 2003); however, these mutations are rare. Currently, extensive genomic scans have not identified universal polymorphisms for diabetes susceptibility (i.e. polymorphisms present with sufficient frequency to be considered causative).

Susceptibility to developing an adult phenotype such as type 2 diabetes is probably a result of both genetic and early environmental factors, with different factors having predominance in different individuals. The 'thrifty phenotype' hypothesis (Hales \& Barker, 1992) proposes that the components of the metabolic syndrome originate from environmental influences and that both fetal and early nutrition are important factors. Adaptations associated with fetal malnutrition become detrimental to the health of the offspring if they experience a period of adequate or plentiful nutrition leading to postnatal obesity (Jaquet et al. 2000). Such observations may explain why the prevalence of the metabolic syndrome is low in regions of Africa where poor fetal nutrition is followed by poor postnatal nutrition and high physical activity, but it is markedly higher in populations moving rapidly from poor to increased nutrition and low physical exercise.

There is direct evidence from both human and animal studies to support the 'thrifty phenotype' hypothesis. First, men and women who were in utero during the 'Dutch Hunger Winter' at the end of the Second World War have been shown to have a worse glucose tolerance than those who were not exposed to the famine (Ravelli et al. 1998). Second, among homozygotic twins it is the twin with the lower mean birth weight that is more susceptible to diabetes (Poulsen et al. 1997). Third, the offspring of mothers who smoke during pregnancy (a known cause of low birth weight) are more likely to become obese (Toschke et al. 2002) and develop type 2 diabetes (Montgomery \& Ekbom, 2002).

\section{Experimental models of early growth restriction}

In an attempt to understand the molecular basis of the relationship between early growth restriction and the development of adult disease, several animal models have been developed. These models employ uterine artery ligation, nutritional interventions (e.g. protein or energy restriction, $\mathrm{Fe}$ deficiency) and hormonal insults, including overexposure to glucocorticoids.

The maternal low-protein model is one of the mostextensively-studied models (Ozanne \& Hales, 1999). Pregnant rat dams are fed a diet containing $80 \mathrm{~g}$ protein/ $\mathrm{kg}$ during pregnancy and lactation that has no observable detrimental effect on litter size or viability. The resulting pups from these litters have a reduced birth weight of approximately $15 \%$. At $21 \mathrm{~d}$ of age both control and lowprotein offspring are weaned onto standard chow containing $200 \mathrm{~g}$ protein $/ \mathrm{kg}$, yet the reduction in body weight of the low-protein offspring is maintained throughout life (Desai et al. 1996).

In early adult life the low-protein offspring are more glucose tolerant and insulin sensitive than the controls (Langley et al. 1994; Hales et al. 1996). There is, however, an age-dependent impairment in glucose tolerance; by 15 months of age there is markedly worsened glucose tolerance and by 17 months the male low-protein offspring are diabetic with elevated insulin levels. The deterioration can be accelerated by high-fat feeding (Wilson \& Hughes, 1997; Stocker et al. 2004). Blood pressure is also raised (Langley-Evans et al. 1996; Petry et al. 1997; CJ Stocker, unpublished results)

Absolute organ growth in growth-restricted low-protein offspring is reduced, but not uniformly (Desai et al. 1996). Brain growth is spared and as a proportion of body weight it is greater in the low-protein offspring. This factor may not reflect brain function, as vascularisation of the developing brain is permanently reduced in these animals (Bennis-Taleb et al. 1999). By contrast, the pancreas shows reduced $\beta$-cell proliferation, islet size, vascularisation (Snoeck et al. 1990) and a reduction in islet cell function (Cherif et al. 1998). In the adult impairment of glucose-stimulated insulin secretion is observed in response to a dietary insult such as high-fat feeding (Wilson \& Hughes, 1997).

The impact of maternal protein restriction on metabolic programming is most pronounced in the insulin-sensitive tissues. The liver from 3-month-old low-protein male rats is resistant to the stimulatory effect of glucagon on glucose output (Ozanne et al. 1996) and has increased phosphoenolpyruvate carboxykinase activity (Desai et al. 1997), both indicative of reduced gluconeogenic activity. Glucose uptake by skeletal muscle is more sensitive to insulin. These findings are consistent with improved glucose tolerance at this age. The age-dependent loss in glucose tolerance is reflected in isolated muscle studies and is thought to be through a defect in insulin action downstream of the receptor (Ozanne et al. 2003). It may in part be a result of permanent changes in mitochondrial function in both the liver and muscle (Park et al. 2003).

Glucose uptake in adipocytes is also more sensitive to insulin in 3-month-old offspring of low-protein dams (Ozanne et al. 1997). This finding is consistent with increased insulin receptor substrate 1-associated phosphatidylinositol 3-kinase activity. However, intra-abdominal adipocytes are resistant to the anti-lipolytic action of insulin (Ozanne \& Hales, 1999) and more sensitive to the lipolytic actions of catecholamines. Plasma catecholamine levels and NEFA levels are raised (Petry et al. 2000). Thus, this phenotype of low-protein offspring is like that of normal fasted rats and may aid survival in animals exposed to intermittent or poor nutrition (Hales \& Ozanne, 2003). As with muscle there is an age-dependent loss in adipocyte function by 15 months of age (Ozanne, 2001) as a result of a defect in insulin signalling and reduced phosphatidylinositol 3-kinase activation. 
The molecular mechanisms underlying these programming events are under investigation. Proteome analysis of isolated fetal islets from maternal protein-restricted pregnancies has highlighted a complex pattern of changes in islets (Sparre et al. 2003). In the liver and kidney of young adult low-protein rats, the binding activity of the nuclear transcription factor HNF1 $\alpha$ is reduced, as is the expression of the downstream signals (Hales \& Ozanne, 2003). Epigenetic mechanisms that regulate chromatin conformation and imprinted genes regulated by cytosine methylation are sensitive to nutritional influences (Waterland \& Jirtle, 2003) and may lead to programmed alterations in metabolism.

\section{Glucocorticoid programming of the fetus}

Fetal overexposure to maternal glucocorticoids in both human and animal models triggers programming events in utero (Langley-Evans et al. 1996; Nyirenda et al. 1998) that establish increases in glucocorticoid action throughout life (Nyirenda et al. 1998; Lesage et al. 2001) and result in a metabolic syndrome. Moreover, exogenous glucocorticoids also retard fetal and placental growth and lower birth weight in both animal models and in man (Hofmann et al. 2001). These effects of the glucocorticoids appear to be relevant to epidemiology because there are strong correlations between birth weight, plasma cortisol concentrations and the development of hypertension and type 2 diabetes (Phillips et al. 2000). Fetal cortisol levels are increased in human fetuses following intrauterine growth-restriction and in pregnancies complicated by pre-eclampsia (Goland et al. 1995), and low birth weight has been shown to predict increased plasma cortisol levels in independent adult populations (Phillips et al. 2000). Since perinatal exposure to glucocorticoids increases the activity of the hypothalamic-pituitary-adrenal axis (Holmes et al. 2003), it has been proposed (for review, see Matthews, 2002) that the programming of this axis in utero is linked to modifications in not only behavioural and neurological responses, but also endocrine and cardiovascular function, regardless of the environment into which the fetus will be born.

Glucocorticoid action within cells is regulated by the expression of the glucocorticoid receptor and two isoforms

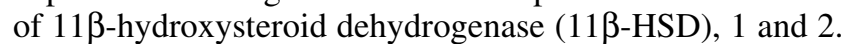
$11 \beta$-HSD-1 acts in vivo primarily as a reductase, catalysing the conversion of cortisone to bioactive cortisol (11dehydrocorticosterone to corticosterone in rats) and amplifying glucocorticoid action at its receptor. The 11ß-HSD-2 isoform acts as a dehydrogenase and catalyses the inactivation of cortisol to corticosterone (Brown et al. 1996). Fetal glucocorticoid levels are lower than maternal levels and this differential is ensured by the high fetoplacental expression of 11ß-HSD-2 (Condon et al. 1998), although this enzyme is not a complete barrier to maternal glucocorticoids (Benediktsson et al. 1997). It has therefore been proposed that a relative deficiency of placental $11 \beta$ HSD-2 will allow increased exposure of the fetus to maternal glucocorticoid levels, retard growth and programme responses that lead to later adult disease. In support of this proposal deleterious mutations of the $11 \beta$-HSD- 2 gene in man are associated with reduced birth weight (DaveSharma et al. 1998), and in rats the offspring of dams given the non-selective $11 \beta$-HSD inhibitor carbenoxolone in pregnancy have reduced birth weight, hypertension and hyperinsulinaemia (Lindsay et al. 1996). Dietary protein restriction attenuates $11 \beta$-HSD-2 in the placenta (LangleyEvans et al. 1996), and this response may be one mechanism linking the maternal environment with fetal programming. In this model administration of glucocorticoid-synthesis inhibitors to the pregnant dam prevents hypertension in the female offspring (Langley-Evans, 1997).

\section{Energy balance}

Neonatal nutrition appears to have long-term effects on appetite (Vickers et al. 2000), but how it influences central mechanisms that regulate food intake and energy balance is ill-defined. There is evidence in rodents, however, for a role of leptin in the development of the brain, particularly within specific hypothalamic regions associated with energy homeostasis (Bouret et al. 2004). The postnatal surge in leptin may serve as a key developmental signal to the hypothalamus and influence subsequent food intake and body weight throughout later life (Ahima et al. 1998; Proulx et al. 2002).

As well as increasing appetite, maternal protein restriction, at least in rodents, programmes the expression of lipogenic genes in the offspring (Maloney et al. 2003). In sheep enhanced fat deposition is seen in late gestation in fetuses that have experienced a period of nutrient restriction (Symonds et al. 2003). Not only is adipogenesis increased, but both rodent and human low-birth-weight offspring have reduced lean mass (Gale et al. 2001).

In addition to nutrition in utero the level of nutrition during lactation correlates with appetite in later life (Vickers et al. 2000; Ozanne et al. 2004). In studies of small-for-gestational-age infants an increased rate of postnatal weight gain ('catch-up growth') is associated with reduced satiety (Ounsted \& Sleigh, 1975). Offspring of malnourished mice cross-fostered onto normally-fed animals rapidly gain weight, possibly as a result of suppressed thermogenesis (Crescenzo et al. 2003), and at weaning catch up with the growth of control litters. These animals are more susceptible to obesity and have reduced longevity (Ozanne \& Hales, 2004). In human populations a period of catch-up growth is associated with an increased risk of elevated blood pressure (Leon et al. 1996), CVD (Eriksson et al. 1999) and type 2 diabetes (Soto et al. 2003), as well as a disproportionately high rate of fat deposition.

Of intense debate is the question of whether bottlefeeding or breast-feeding is more beneficial to the longterm health of the infant. Many studies have reported that breast-fed infants show a different growth pattern from formula-fed infants (Agostoni et al. 1999). Breast-fed infants are leaner and are protected from becoming obese when older (for review, see Locke, 2002). These differences may in part be a result of a different endocrine 
(a)

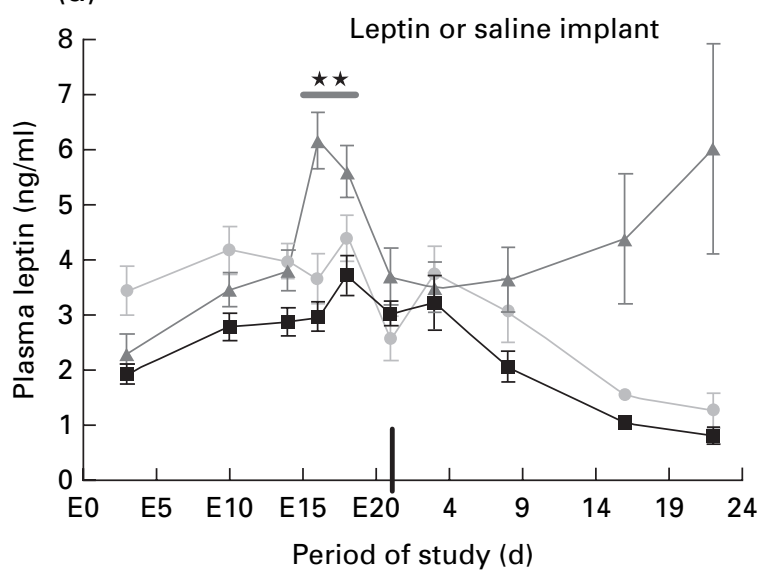

(c)

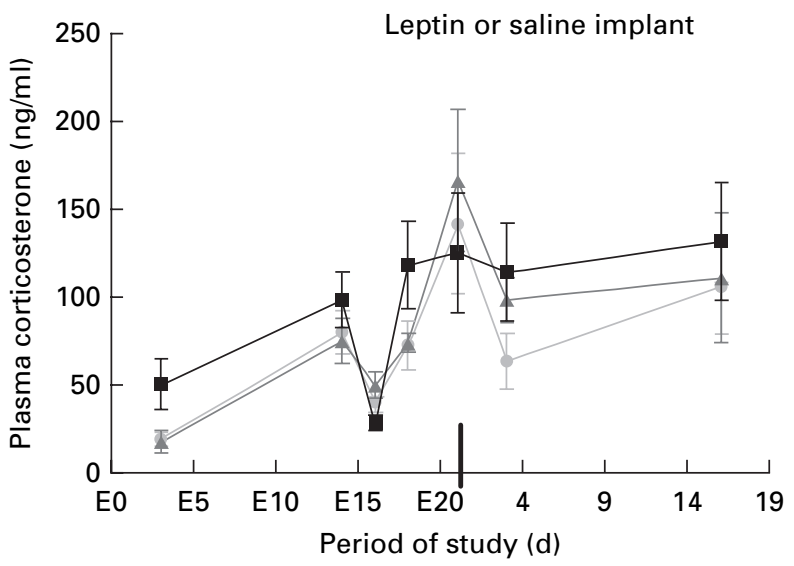

(b)

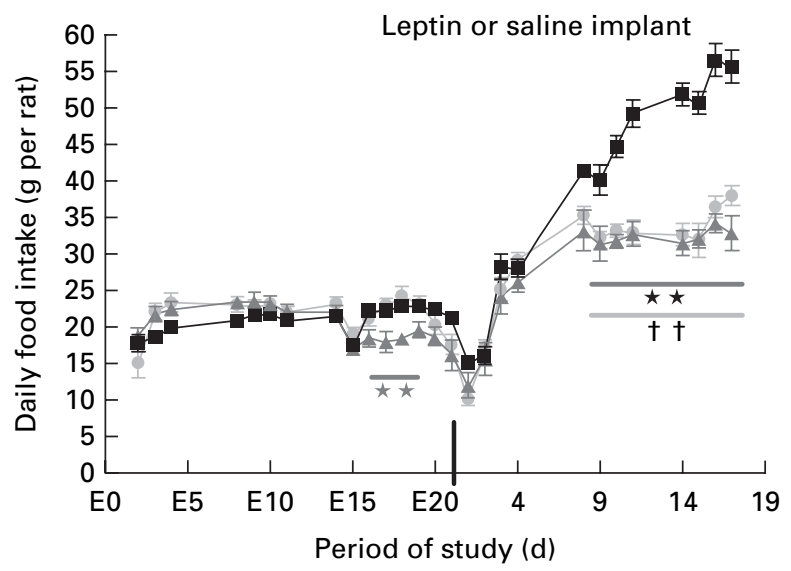

(d)

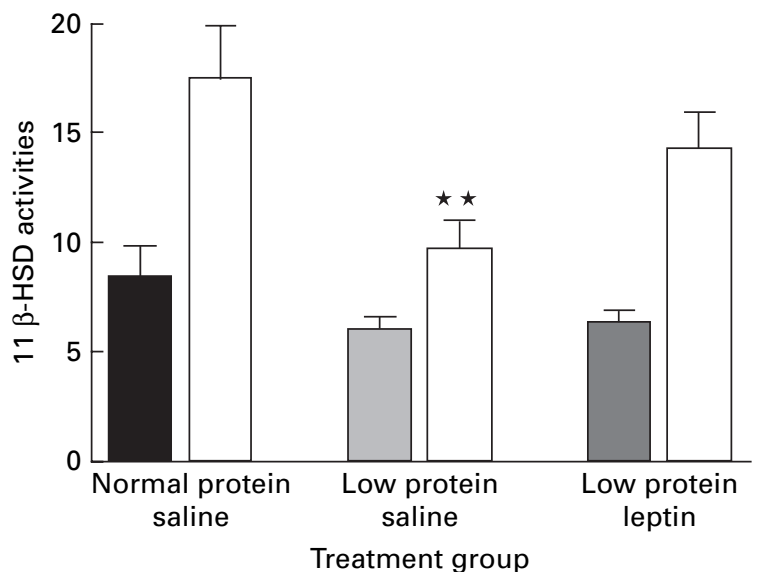

Fig. 1. Plasma leptin levels (a) and daily food intake (b) and plasma corticosterone levels (c) for rat dams fed on a normal-protein diet $(200 \mathrm{~g} / \mathrm{kg})$ and infused with saline $(9 \mathrm{~g}$ sodium chloride/l; $)$ ), or fed on a low-protein diet $(80 \mathrm{~g} / \mathrm{kg})$ and infused with either leptin (A) or saline $(\bullet)$ during pregnancy $(E)$ and lactation. (I), Parturition. Values are means with their standard errors for twelve pregnant dams per group. Mean values for low-protein leptin-infused dams were significantly different from those for normal-protein dams: ${ }^{\star \star} P<0 \cdot 01$. Mean values for low-protein saline-infused dams were significantly different from those for normal-protein dams: $\dagger \dagger P<0.01$. (d) Placental 11 dehydrogenase (11ß-HSD) type $1(\mathbf{\square})$ and type $2(\square)$ activities expressed as the percentage conversion of corticosterone to dehydrocorticosterone. Values are means with their standard errors for six to eight placentas per group from mixed litters. Mean value for $11 \beta$-HSD type 2 for low-protein saline-infused dams was significantly different from that for normal-protein dams: ${ }^{\star \star} P<0.01$.

response to feeding. Leptin is present in breast milk, but not infant formula (Savino et al. 2002). Breast-fed infants appear to have a different ability to regulate food intake both when breast-feeding (Dewey et al. 1993) and when eating solid food (Perez-Escamilla et al. 1995). This difference raises the possibility that the presence of leptin in breast milk has a positive effect on satiety and the regulation of energy balance (Dessolin et al. 1997).

Leptin's role in breast milk may not be limited to energy regulation and metabolism. It may be important in the continued development of the organ systems, e.g. the gastrointestinal tract and the immune system. The level of cord blood leptin is inversely related to rates of growth during infancy in human studies (Ong et al. 1999), and low-birth-weight infants have reduced leptin levels. Early growth rates are strongly influenced by a drive to compensate for earlier intrauterine growth restriction or antenatal restraints, which may involve the programming of appetite (Ong et al. 2002).

\section{Leptin in pregnancy}

Maternal leptin is produced from adipose stores and the placenta. During pregnancy and lactation it modulates energy expenditure and metabolism, as well as lactation itself. It also affects placental growth, nutrient transfer (Jansson et al. 2003), angiogenesis and trophoblast invasion (for review, see Sagawa et al. 2002). Placental function has been shown to be impaired in pregnancies in which the fetus is growth-retarded through the downregulation of specific amino acid transport proteins (Glazier et al. 1997). Consistent with these observations, transplacental passage of leptin is reduced (Smith \& 
Waddell, 2003). Fetal leptin produced from both fetal adipocytes and the placenta is secreted into the amniotic fluid and stimulates fetal growth and development, fetal angiogenesis and haematopoiesis. Leptin levels increase throughout gestation, peak in the second trimester and remain high until parturition. These elevated levels are not associated with negative energy balance as might be expected, perhaps because leptin resistance in pregnancy sustains maternal food intake for fetal growth (Seeber et al. 2002).

\section{The role of leptin in fetal growth and development}

There is accumulating evidence to suggest that leptin production from the placenta and fetal adipose tissue, and in rodents from the maternal circulation (Smith \& Waddell, 2003), acts through fetal leptin receptors to regulate fetal growth and development. In part, this effect of leptin is a result of a direct influence on the insulin and the insulin-like growth factor-growth hormone systems. Leptin levels in umbilical cord blood are positively correlated with birth weight and neonatal adiposity. Leptin may play a role in the control of substrate utilisation and in the maintenance and functional characteristics of fat mass before birth (Bispham et al. 2003; Yuen et al. 2003), producing permanent effects on adiposity and body composition in adult life (Nilsson et al. 2003). Postnatal leptin levels, which are predominantly regulated by nutrition, also play a key role (Ehrhardt et al. 2003). For example, suboptimal nutrition leads to a delay in the onset of puberty, and it is likely that leptin may contribute to this effect (Léonhardt et al. 2003). Leptin levels in neonates decrease rapidly following birth and this rapid decline may be an important stimulus of feeding behaviour in early life. This process may be one explanation for why growthrestricted babies exhibiting low leptin levels at birth have increased growth rates in early neonatal life.

\section{A role for leptin in the programming of metabolic disease?}

An aim has been to address whether leptin is involved in the programming of adult metabolic disease in low-birthweight rodents, either by acting directly on fetal leptin receptors, or indirectly via maternal or placental receptors. Reports that administration of leptin prevents the endocrine response to fasting (Ahima et al. 1996) and potently suppresses the secretion of glucocorticoids (Proulx et al. 2001) have been encouraging. To investigate the role of leptin in fetal programming the maternal protein-restricted rat model of intrauterine growth restriction has been used.

Pregnant rat dams were fed either an $80 \mathrm{~g}$ protein $/ \mathrm{kg}$ diet or control chow throughout pregnancy and lactation. At the beginning of the third trimester a continuous infusion of either saline $(9 \mathrm{~g} \mathrm{NaCl} / \mathrm{l})$ or leptin was given utilising a subcutaneously-implanted osmotic mini-pump. Following infusion of leptin, leptin levels were found to be elevated fivefold in the low-protein-fed dams as compared with both low-protein and control-protein saline $(9 \mathrm{~g} \mathrm{NaCl} / \mathrm{l})$ treated groups. Despite late pregnancy being a state of apparent leptin resistance in rodents, food intake is reduced

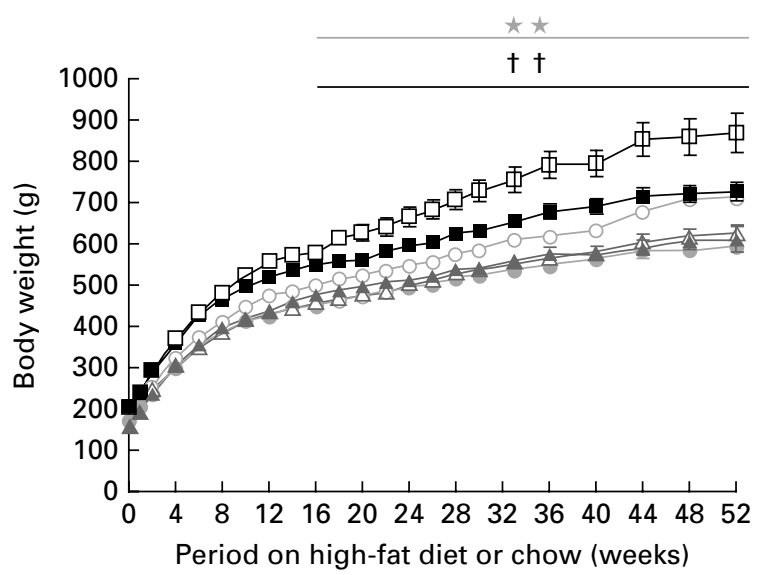

Fig. 2. Effect of maternal leptin treatment on body weight for chow-fed $(\boldsymbol{\square}, \boldsymbol{\Delta}, \boldsymbol{\bullet})$ and high-fat-fed $(68 \%$ fat as metabolisable energy; $\square, \triangle, \bigcirc)$ offspring of rat dams fed on a normal-protein $(200 \mathrm{~g} / \mathrm{kg})$ diet and infused with saline $(9 \mathrm{~g} \mathrm{NaCl} / \mathrm{\square} ; \square)$ or fed on a low-protein $(80 \mathrm{~g} / \mathrm{kg})$ diet and infused with either leptin $(\boldsymbol{\Lambda}, \triangle)$ or saline $(\bullet, \bigcirc)$ during pregnancy and lactation. Values are means with their standard errors for sixteen offspring per group. There was a significant increase in the body weights of offspring fed on the high-fat diet compared with offspring fed on chow for offspring of dams fed on a low-protein diet and treated with saline during pregnancy and lactation: ${ }^{* *} P<0 \cdot 01$. There was a significant increase in the body weights of offspring fed on the high-fat diet compared with offspring fed on chow for offspring of dams fed on a normal-protein diet and treated with saline during pregnancy and lactation: $\dagger \dagger P<0.01$.

in the low-protein leptin-treated group. Following parturition, absolute food intake is suppressed in both the salineand leptin-treated low-protein groups compared with the normal-protein group (Fig. 1a,b).

Fetal weights are reduced in both the low-protein groups. Placental weights are also lower in the saline-treated low-protein diet group as compared with those in the normal-protein diet group, which results in an increased fetal:placental weight. Maternal leptin administration reduces fetal:placental weight to that of the control group, suggesting that elevating leptin levels in the low-protein dams may have prevented any placental insufficiency as a result of placental size. Levels of circulating maternal glucocorticoids are not significantly affected by dietary intervention or leptin administration. However, while the activity of placental $11 \beta$-HSD- 1 is similar in all groups, that of $11 \beta$-HSD-2 is significantly reduced in the salinetreated low-protein dams $(P<0 \cdot 01)$ but not in those treated with leptin (Fig. 1c,d). This finding is consistent with a role for glucocortocoids in programming the fetus to increased susceptibility to adult disease, and may be an important mechanism by which in early life leptin can modulate the susceptibility of the offspring to later adult disease (Stocker et al. 2004).

Evidence is now available to suggest that leptin may directly influence fetal growth and development through the insulin-like growth factor-growth hormone axis (CJ Stocker, unpublished results). Leptin administration to low-protein dams partially reverses the reduction in fetal insulin-like growth factor 1 levels in the intrauterine 
(a)

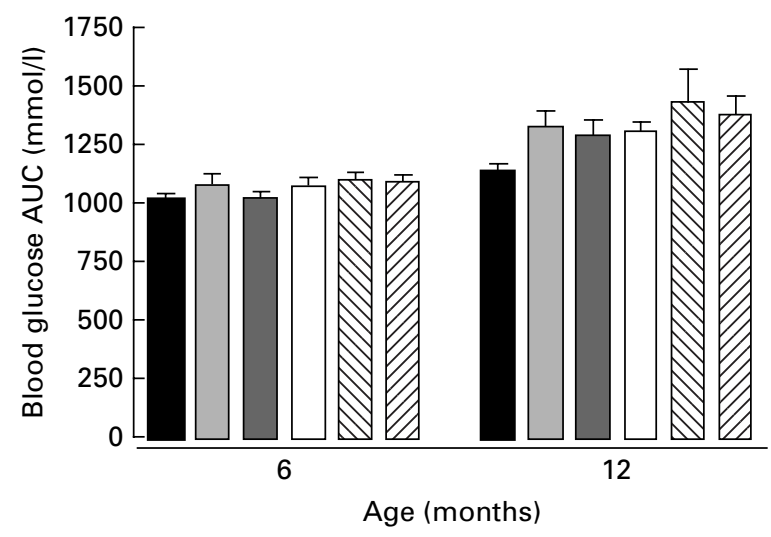

(c)

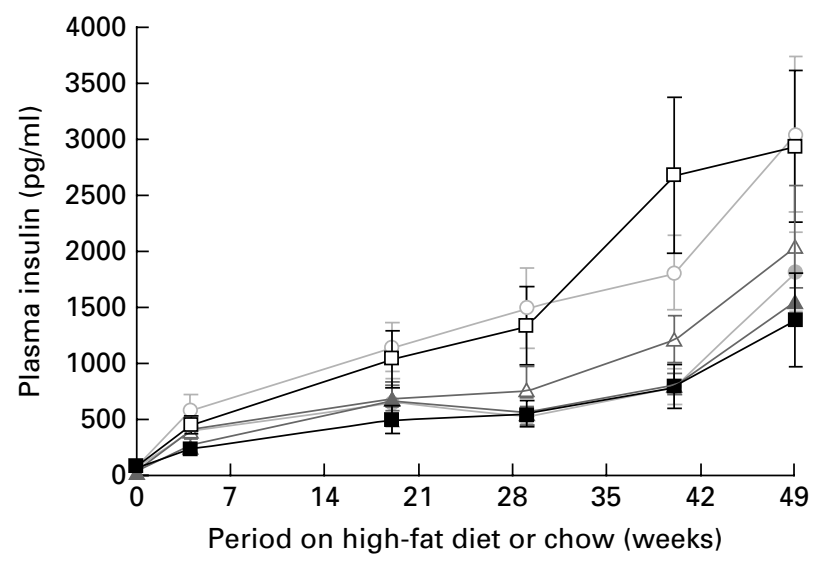

(b)

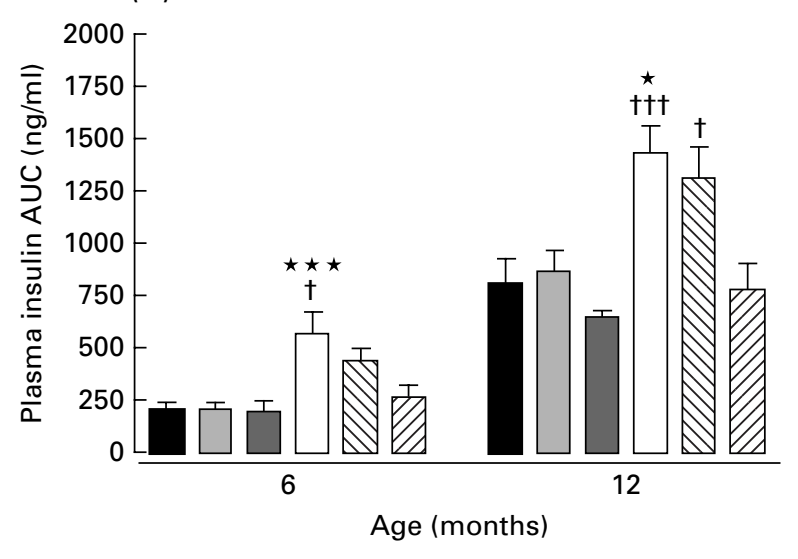

(d)

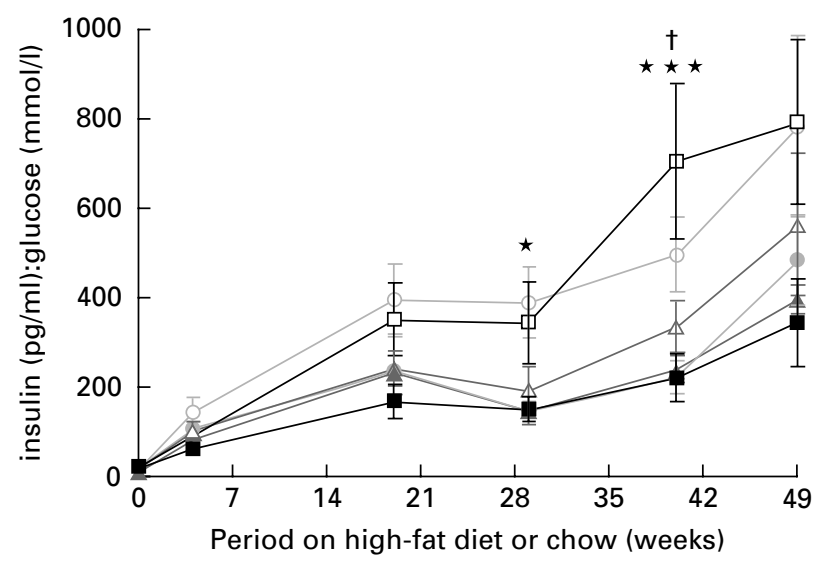

Fig. 3. Area under the curve (AUC) for blood glucose (a) and plasma insulin (b) concentrations during a glucose tolerance test for chow-fed $(\boldsymbol{\square}, \square, \square)$ and high-fat-fed $(\square, \nabla, \nabla) 6$ - and 12-month-old male offspring of rat dams fed on a normal-protein (200 g/kg) diet infused with saline $(9 \mathrm{~g} \mathrm{NaCl} / \mathrm{l} ; \square, \square)$ or a low-protein $(80 \mathrm{~g} / \mathrm{kg})$ diet infused with either leptin $(\square, \nabla)$ or saline ( $\square$, $\nabla)$ during pregnancy and lactation. Fasting insulin (c) and fasting insulin:fasting glucose (d) for chow-fed ( $\boldsymbol{\square}, \mathbf{\Delta}, \mathbf{O})$ and high-fat-fed $(\square, \triangle, \bigcirc)$ male offspring of dams fed on a normal-protein diet and infused with saline $(\boldsymbol{\square}, \square)$ or fed on a low-protein diet and infused with either leptin $(\boldsymbol{\Delta}, \triangle)$ or saline ( $\bigcirc$, during pregnancy and lactation. For a-d, values are means with their standard errors for six to eight offspring per group. Mean values were significantly different from those for chow-fed offspring of dams receiving the same treatment during pregnancy and lactation: ${ }^{*}<0.05$, ${ }^{\star \star \star} P<0.001$. Mean values were significantly different from those for high-fat-fed offspring of dams fed on a low-protein diet and infused with leptin during pregnancy and lactation: $\uparrow P<0.05, \uparrow \dagger \uparrow P<0.001$.

growth restriction offspring and significantly elevates both insulin-like growth factor 2 and fetal leptin levels. These elevated maternal and/or fetal leptin and insulin-like growth factor levels affect the development of key endocrine organs, e.g. the pancreas. Maternal leptin administration results in alterations of pancreatic hormone levels, including an increase in pancreatic insulin content to a level comparable with those in offspring from normalprotein dams.

The birth weights of the leptin-treated low-protein-diet group are lower than those for both the saline-treated lowprotein and the normal-protein groups (Stocker et al. 2001). This difference in body weight continues throughout lactation and into adulthood in both the male and female offspring. At weaning this reduction in body weight in the offspring from the leptin-treated low-protein-diet groups is reflected by a decrease in adipose tissue in the males but not females. This finding suggests a role for leptin in the programming of adipose development. In support of this role, it has been shown that when these offspring are placed on a highly-palatable high-fat diet (68\% fat as metabolisable energy) from 6 weeks of age the offspring of the leptin-treated mothers are completely resistant to the weight gain associated with this feeding regimen (Fig. 2). This resistance to high-fat-diet-induced weight gain may in part be a result of the elevated metabolic rate in the young adult offspring from leptintreated dams (CJ Stocker, unpublished results). These offspring are also more insulin sensitive following an intraperitoneal glucose tolerance test (Fig. 3). Thus, the glucose tolerance profile is similar in all groups of 6- and 12-month-old male rats irrespective of dietary treatment or maternal group. However, with the exception of those offspring from mothers receiving leptin, rats fed on a highfat diet are hyperinsulinaemic both in the fasted state and during the glucose tolerance test. 
An individual's susceptibility to later metabolic disease is probably influenced by poor nutrition at particular times during early development and confounded by later postnatal nutritional excess, interacting with genetics. Data from investigations into whether leptin might play a role in this process collectively suggest that leptin influences the early-life metabolic programming events occurring in the offspring of an intrauterine growth-restricted pregnancy, but the precise timing and relative contribution of the effects are likely to be complex. Leptin administration in both pregnancy and lactation has been shown to provide long-term protection from type 2 diabetes and obesity. The clinical relevance of these observations has yet to be established.

\section{References}

Agostoni C, Grandi F, Gianni ML, Silano M, Torcoletti M, Giovannini M \& Riva E (1999) Growth patterns of breast fed and formula fed infants in the first 12 months of life: an Italian study. Archives of Disease in Childhood 81, 395-399.

Ahima RS, Prabakaran D \& Flier JS (1998) Postnatal leptin surge and regulation of circadian rhythm of leptin by feeding. Implications for energy homeostasis and neuroendocrine function. Journal of Clinical Investigation 101, 1020-1027.

Ahima RS, Prabakaran D, Mantzoros C, Qu D, Lowell B, Maratos-Flier E \& Flier JS (1996) Role of leptin in the neuroendocrine response to fasting. Nature 382, 250-252.

Barker DJ, Hales CN, Fall CH, Osmond C, Phipps K \& Clark PM (1993) Type 2 (non-insulin-dependent) diabetes mellitus, hypertension and hyperlipidaemia (syndrome $\mathrm{X}$ ): relation to reduced fetal growth. Diabetologia 36, 62-67.

Benediktsson R, Calder AA, Edwards CR \& Seckl JR (1997) Placental 11 beta-hydroxysteroid dehydrogenase: a key regulator of fetal glucocorticoid exposure. Clinical Endocrinology 46, 161-166.

Bennis-Taleb N, Remacle C, Hoet JJ \& Reusens B (1999) A lowprotein isocaloric diet during gestation affects brain development and alters permanently cerebral cortex blood vessels in rat offspring. Journal of Nutrition 129, 1613-1619.

Bispham J, Gopalakrishnan GS, Dandrea J, Wilson V, Budge H, Keisler DH, Broughton Pipkin F, Stephenson T \& Symonds ME (2003) Maternal endocrine adaptation throughout pregnancy to nutritional manipulation: consequences for maternal plasma leptin and cortisol and the programming of fetal adipose tissue development. Endocrinology 144, 3575-3585.

Bouret SG, Draper SJ \& Simerly RB (2004) Trophic action of leptin on hypothalamic neurons that regulate feeding. Science 304, 108-110.

Brown RW, Chapman KE, Kotelevtsev Y, Yau JL, Lindsay RS, Brett L et al. (1996) Cloning and production of antisera to human placental 11 beta-hydroxysteroid dehydrogenase type 2 . Biochemical Journal 313, 1007-1017.

Cherif H, Reusens B, Ahn MT, Hoet JJ \& Remacle C (1998) Effects of taurine on the insulin secretion of rat fetal islets from dams fed a low-protein diet. Journal of Endocrinology 159, 341-348.

Condon J, Gosden C, Gardener D, Nickson P, Hewison M, Howie AJ \& Stewart PM (1998) Expression of type 2 11betahydroxysteroid dehydrogenase and corticosteroid hormone receptors in early human fetal life. Journal of Clinical Endocrinology and Metabolism 83, 4490-4497.

Crescenzo R, Samec S, Antic V, Rohner-Jeanrenaud F, Seydoux J, Montani JP \& Dulloo AG (2003) A role for suppressed thermogenesis favoring catch-up fat in the pathophysiology of catch-up growth. Diabetes 52, 1090-1097.

Dave-Sharma S, Wilson RC, Harbison MD, Newfield R, Azar MR, Krozowski ZS et al. (1998) Examination of genotype and phenotype relationships in 14 patients with apparent mineralocorticoid excess. Journal of Clinical Endocrinology and Metabolism 83, 2244-2254.

Desai M, Byrne CD, Zhang J, Petry CJ, Lucas A \& Hales CN (1997) Programming of hepatic insulin-sensitive enzymes in offspring of rat dams fed a protein-restricted diet. American Journal of Physiology 272, G1083-G1090.

Desai M, Crowther NJ, Lucas A \& Hales CN (1996) Organselective growth in the offspring of protein-restricted mothers. British Journal of Nutrition 76, 591-603.

Dessolin S, Schalling M, Champigny O, Lonnqvist F, Ailhaud G, Dani C \& Ricquier D (1997) Leptin gene is expressed in rat brown adipose tissue at birth. FASEB Journal 11, 382-387.

Dewey KG, Heinig MJ, Nommsen LA, Peerson JM \& Lonnerdal B (1993) Breast-fed infants are leaner than formula-fed infants at $1 \mathrm{y}$ of age: the DARLING study. American Journal of Clinical Nutrition 57, 140-145.

Ehrhardt RA, Greenwood PL, Bell AW \& Boisclair YR (2003) Plasma leptin is regulated predominantly by nutrition in preruminant lambs. Journal of Nutrition 133, 4196-4201.

Eriksson JG, Forsen T, Tuomilehto J, Winter PD, Osmond C \& Barker DJ (1999) Catch-up growth in childhood and death from coronary heart disease: longitudinal study. British Medical Journal 318, 427-431.

Fall CH (2001) Non-industrialised countries and affluence. British Medical Bulletin 60, 33-50.

Frayling TM \& Hattersley AT (2001) The role of genetic susceptibility in the association of low birth weight with type 2 diabetes. British Medical Bulletin 60, 89-101.

Gale CR, Martyn CN, Kellingray S, Eastell R \& Cooper C (2001) Intrauterine programming of adult body composition. Journal of Clinical Endocrinology and Metabolism 86, 267-272.

Glazier JD, Cetin I, Perugino G, Ronzoni S, Grey AM, Mahendran D, Marconi AM, Pardi G \& Sibley CP (1997) Association between the activity of the system A amino acid transporter in the microvillous plasma membrane of the human placenta and severity of fetal compromise in intrauterine growth restriction. Pediatric Research 42, 514-519.

Goland RS, Tropper PJ, Warren WB, Stark RI, Jozak SM \& Conwell IM (1995) Concentrations of corticotrophin-releasing hormone in the umbilical-cord blood of pregnancies complicated by pre-eclampsia. Reproduction, Fertility, and Development 7, 1227-1230.

Hales CN \& Barker DJ (1992) Type 2 (non-insulin-dependent) diabetes mellitus: the thrifty phenotype hypothesis. Diabetologia 35, 595-601.

Hales CN, Barker DJ, Clark PM, Cox LJ, Fall C, Osmond C \& Winter PD (1991) Fetal and infant growth and impaired glucose tolerance at age 64. British Medical Journal 303, $1019-1022$.

Hales CN, Desai M, Ozanne SE \& Crowther NJ (1996) Fishing in the stream of diabetes: from measuring insulin to the control of fetal organogenesis. Biochemical Society Transactions 24, 341-350.

Hales CN \& Ozanne SE (2003) The dangerous road of catch-up growth. Journal of Physiology 547, 5-10.

Hattersley AT, Beards F, Ballantyne E, Appleton M, Harvey R \& Ellard S (1998) Mutations in the glucokinase gene of the fetus result in reduced birth weight. Nature Genetics 19, 268-270.

Hofmann M, Pollow K, Bahlmann F, Casper F, Steiner E \& Brockerhoff P (2001) 11 beta-hydroxysteroid dehydrogenase (11 beta-HSD-II) activity in human placenta: its relationship to 
placental weight and birth weight and its possible role in hypertension. Journal of Perinatal Medicine 29, 23-30.

Holmes MC, Yau JL, Kotelevtsev Y, Mullins JJ \& Seckl JR (2003) 11 Beta-hydroxysteroid dehydrogenases in the brain: two enzymes two roles. Annals of the New York Academy of Sciences 1007, 357-366.

Jansson N, Greenwood SL, Johansson BR, Powell TL \& Jansson $\mathrm{T}$ (2003) Leptin stimulates the activity of the system A amino acid transporter in human placental villous fragments. Journal of Clinical Endocrinology and Metabolism 88, 1205-1211.

Jaquet D, Gaboriau A, Czernichow P \& Levy-Marchal C (2000) Insulin resistance early in adulthood in subjects born with intrauterine growth retardation. Journal of Clinical Endocrinology and Metabolism 85, 1401-1406.

Langley SC, Browne RF \& Jackson AA (1994) Altered glucose tolerance in rats exposed to maternal low protein diets in utero. Comparative Biochemistry and Physiology 109, 223-229.

Langley-Evans SC (1997) Hypertension induced by foetal exposure to a maternal low-protein diet, in the rat, is prevented by pharmacological blockade of maternal glucocorticoid synthesis. Journal of Hypertension 15, 537-544.

Langley-Evans SC, Phillips GJ, Benediktsson R, Gardner DS, Edwards CR, Jackson AA \& Seckl JR (1996) Protein intake in pregnancy, placental glucocorticoid metabolism and the programming of hypertension in the rat. Placenta 17, 169-172.

Leon DA, Koupilova I, Lithell HO, Berglund L, Mohsen R, Vagero D, Lithell UB \& McKeigue PM (1996) Failure to realise growth potential in utero and adult obesity in relation to blood pressure in 50 year old Swedish men. British Medical Journal 312, 401-406.

Léonhardt M, Lesage J, Croix D, Dutriez-Casteloot I, Beauvillain JC \& Dupouy JP (2003) Effects of perinatal maternal food restriction on pituitary-gonadal axis and plasma leptin level in rat pup at birth and weaning and on timing of puberty. Biology of Reproduction 68, 390-400.

Lesage J, Blondeau B, Grino M, Breant B \& Dupouy JP (2001) Maternal undernutrition during late gestation induces fetal overexposure to glucocorticoids and intrauterine growth retardation, and disturbs the hypothalamo-pituitary adrenal axis in the newborn rat. Endocrinology 142, 1692-1702.

Lindsay RS, Lindsay RM, Waddell BJ \& Seckl JR (1996) Prenatal glucocorticoid exposure leads to offspring hyperglycaemia in the rat: studies with the 11 beta-hydroxysteroid dehydrogenase inhibitor carbenoxolone. Diabetologia 39, $1299-1305$.

Locke R (2002) Preventing obesity: the breast milk-leptin connection. Acta Paediatrica 91, 891-894.

Maloney CA, Gosby AK, Phuyal JL, Denyer GS, Bryson JM \& Caterson ID (2003) Site-specific changes in the expression of fat-partitioning genes in weanling rats exposed to a low-protein diet in utero. Obesity Research 11, 461-468.

Matthews SG (2002) Early programming of the hypothalamopituitary-adrenal axis. Trends in Endocrinology and Metabolism 13, 373-380.

Montgomery SM \& Ekbom A (2002) Smoking during pregnancy and diabetes mellitus in a British longitudinal birth cohort. British Medical Journal 324, 26-27.

Newsome CA, Shiell AW, Fall CH, Phillips DI, Shier R \& Law CM (2003) Is birth weight related to later glucose and insulin metabolism? - A systematic review. Diabetic Medicine 20, 339-348.

Nilsson C, Swolin-Eide D, Ohlsson C, Eriksson E, Ho HP, Bjorntorp P \& Holmang A (2003) Reductions in adipose tissue and skeletal growth in rat adult offspring after prenatal leptin exposure. Journal of Endocrinology 176, 13-21.

Njolstad PR, Sagen JV, Bjorkhaug L, Odili S, Shehadeh N, Bakry D et al. (2003) Permanent neonatal diabetes caused by glucokinase deficiency: inborn error of the glucose-insulin signaling pathway. Diabetes 52, 2854-2860.

Nyirenda MJ, Lindsay RS, Kenyon CJ, Burchell A \& Seckl JR (1998) Glucocorticoid exposure in late gestation permanently programs rat hepatic phosphoenolpyruvate carboxykinase and glucocorticoid receptor expression and causes glucose intolerance in adult offspring. Journal of Clinical Investigation 101, 2174-2181.

Ong KK, Ahmed ML, Sherriff A, Woods KA, Watts A, Golding J \& Dunger DB (1999) Cord blood leptin is associated with size at birth and predicts infancy weight gain in humans. ALSPAC Study Team. Avon Longitudinal Study of Pregnancy and Childhood. Journal of Clinical Endocrinology and Metabolism 84, 1145-1148.

Ong KK, Preece MA, Emmett PM, Ahmed ML \& Dunger DB (2002) Size at birth and early childhood growth in relation to maternal smoking, parity and infant breast-feeding: longitudinal birth cohort study and analysis. Pediatric Research 52, 863-867.

Ounsted M \& Sleigh G (1975) The infant's self-regulation of food intake and weight gain. Difference in metabolic balance after growth constraint or acceleration in utero. Lancet $\mathbf{i}$, 1393-1397.

Ozanne SE (2001) Metabolic programming in animals. British Medical Bulletin 60, 143-152.

Ozanne SE \& Hales CN (1999) The long-term consequences of intra-uterine protein malnutrition for glucose metabolism. Proceedings of the Nutrition Society 58, 615-619.

Ozanne SE \& Hales CN (2004) Lifespan: catch-up growth and obesity in male mice. Nature 427, 411-412.

Ozanne SE, Lewis R, Jennings BJ \& Hales CN (2004) Early programming of weight gain in mice prevents the induction of obesity by a highly palatable diet. Clinical Science 106, 141-145.

Ozanne SE, Nave BT, Wang CL, Shepherd PR, Prins J \& Smith GD (1997) Poor fetal nutrition causes long-term changes in expression of insulin signaling components in adipocytes. American Journal of Physiology 273, E46-E51.

Ozanne SE, Olsen GS, Hansen LL, Tingey KJ, Nave BT, Wang CL, Hartil K, Petry CJ, Buckley AJ \& Mosthaf-Seedorf L (2003) Early growth restriction leads to down regulation of protein kinase $\mathrm{C}$ zeta and insulin resistance in skeletal muscle. Journal of Endocrinology 177, 235-241.

Ozanne SE, Smith GD, Tikerpae J \& Hales CN (1996) Altered regulation of hepatic glucose output in the male offspring of protein-malnourished rat dams. American Journal of Physiology 270, E559-E564.

Park KS, Kim SK, Kim MS, Cho EY, Lee JH, Lee KU, Pak YK \& Lee HK (2003) Fetal and early postnatal protein malnutrition cause long-term changes in rat liver and muscle mitochondria. Journal of Nutrition 133, 3085-3090.

Perez-Escamilla R, Cohen RJ, Brown KH, Rivera LL, Canahuati J \& Dewey KG (1995) Maternal anthropometric status and lactation performance in a low-income Honduran population: evidence for the role of infants. American Journal of Clinical Nutrition 61, 528-534.

Petry CJ, Dorling MW, Wang CL, Pawlak DB \& Ozanne SE (2000) Catecholamine levels and receptor expression in low protein rat offspring. Diabetic Medicine 17, 848-853.

Petry CJ, Ozanne SE, Wang CL \& Hales CN (1997) Early protein restriction and obesity independently induce hypertension in 1-year-old rats. Clinical Science 93, 147-152.

Phillips DI, Walker BR, Reynolds RM, Flanagan DE, Wood PJ, Osmond C, Barker DJ \& Whorwood CB (2000) Low birth weight predicts elevated plasma cortisol concentrations in adults from 3 populations. Hypertension $\mathbf{3 5}$, $1301-1306$ 
Poulsen P, Vaag AA, Kyvik KO, Moller Jensen D \& BeckNielsen H (1997) Low birth weight is associated with NIDDM in discordant monozygotic and dizygotic twin pairs. Diabetologia 40, 439-446.

Proulx K, Clavel S, Nault G, Richard D \& Walker CD (2001) High neonatal leptin exposure enhances brain GR expression and feedback efficacy on the adrenocortical axis of developing rats. Endocrinology 142, 4607-4616.

Proulx K, Richard D \& Walker CD (2002) Leptin regulates appetite-related neuropeptides in the hypothalamus of developing rats without affecting food intake. Endocrinology 143, 4683-4692.

Ravelli AC, van der Meulen JH, Michels RP, Osmond C, Barker DJ, Hales CN \& Bleker OP (1998) Glucose tolerance in adults after prenatal exposure to famine. Lancet 351, 173-177.

Sagawa N, Yura S, Itoh H, Kakui K, Takemura M, Nuamah MA, Ogawa Y, Masuzaki H, Nakao K \& Fujii S (2002) Possible role of placental leptin in pregnancy: a review. Endocrine 19, 65-71.

Savino F, Costamagna M, Prino A, Oggero R \& Silvestro L (2002) Leptin levels in breast-fed and formula-fed infants. Acta Paediatrica 91, 897-902.

Seeber RM, Smith JT \& Waddell BJ (2002) Plasma leptinbinding activity and hypothalamic leptin receptor expression during pregnancy and lactation in the rat. Biology of Reproduction 66, 1762-1767.

Smith JT \& Waddell BJ (2003) Leptin distribution and metabolism in the pregnant rat: transplacental leptin passage increases in late gestation but is reduced by excess glucocorticoids. Endocrinology 144, 3024-3030.

Snoeck A, Remacle C, Reusens B \& Hoet JJ (1990) Effect of a low protein diet during pregnancy on the fetal rat endocrine pancreas. Biology of the Neonate 57, 107-118.

Soto N, Bazaes RA, Pena V, Salazar T, Avila A, Iniguez G, Ong KK, Dunger DB \& Mericq MV (2003) Insulin sensitivity and secretion are related to catch-up growth in small-for-gestational-age infants at age 1 year: results from a prospective cohort. Journal of Clinical Endocrinology and Metabolism 88, $3645-3650$.
Sparre T, Reusens B, Cherif H, Larsen MR, Roepstorff P, Fey SJ, Mose Larsen P, Remacle C \& Nerup J (2003) Intrauterine programming of fetal islet gene expression in rats - effects of maternal protein restriction during gestation revealed by proteome analysis. Diabetologia 46, 1497-1511.

Stocker C, O'Dowd J, Morton NM, Wargent E, Sennitt MV, Hislop D, Glund S, Seckl JR, Arch JR \& Cawthorne MA (2004) Modulation of susceptibility to weight gain and insulin resistance in low birthweight rats by treatment of their mothers with leptin during pregnancy and lactation. International Journal of Obesity and Related Metabolic Disorders 28 129-136.

Stocker C, Wargent E, Sennitt M, Nolan A, O'Dowd J, Subramaniam K, Wang S \& Cawthorne MA (2001) Maternal leptin administration induces resistance to diet-induced obesity of early growth restricted rats. Diabetologia 44, Suppl. 1, 641Abstr.

Symonds ME, Mostyn A, Pearce S, Budge H \& Stephenson T (2003) Endocrine and nutritional regulation of fetal adipose tissue development. Journal of Endocrinology 179, 293-299.

Toschke AM, Koletzko B, Slikker W Jr, Hermann M \& von Kries $\mathrm{R}$ (2002) Childhood obesity is associated with maternal smoking in pregnancy. European Journal of Pediatrics 161, 445-448.

Vickers MH, Breier BH, Cutfield WS, Hofman PL \& Gluckman PD (2000) Fetal origins of hyperphagia, obesity, and hypertension and postnatal amplification by hypercaloric nutrition. American Journal of Physiology 279, E83-E87.

Waterland RA \& Jirtle RL (2003) Transposable elements: targets for early nutritional effects on epigenetic gene regulation. Molecular and Cellular Biology 23, 5293-5300.

Wilson MR \& Hughes SJ (1997) The effect of maternal protein deficiency during pregnancy and lactation on glucose tolerance and pancreatic islet function in adult rat offspring. Journal of Endocrinology 154, 177-185.

Yuen BS, Owens PC, Muhlhausler BS, Roberts CT, Symonds ME, Keisler DH, McFarlane JR, Kauter KG, Evens Y \& McMillen IC (2003) Leptin alters the structural and functional characteristics of adipose tissue before birth. FASEB Journal 17, 1102-1104. 
https://doi.org/10.1079/PNS2005417 Published online by Cambridge University Press 